\title{
Neotropical Monogenoidea. 56. New species of Anacanthorus (Dactylogyridae) from the gills of matrinchã, Brycon orthotaenia (Characiformes: Characidae), in the Rio São Francisco, Brazil
}

\author{
Cassandra M. Monteiro ${ }^{1}$, Delane C. Kritsky ${ }^{2}$ and Marilia C. Brasil-Sato ${ }^{3}$ \\ ${ }^{1}$ Curso de Pós-Graduação em Ciências Veterinárias, Universidade Federal Rural do Rio de Janeiro, Seropédica, Rio de Janeiro, \\ 23890-000, Brazil; \\ ${ }^{2}$ Department of Health and Nutrition Sciences, Campus Box 8090, Idaho State University, Pocatello, Idaho 83209, USA; \\ ${ }^{3}$ Departamento de Biologia Animal, Universidade Federal Rural do Rio de Janeiro, Km 7, Br 465, CP 74539, Seropédica, Rio de \\ Janeiro, 23851-970, Brazil
}

\begin{abstract}
Anacanthorus franciscanus sp. n. and Anacanthorus brevicirrus sp. n. (Dactylogyridae) are described from the gills of the matrinchã, Brycon orthotaenia Günther (Characidae), from the Rio São Francisco in Brazil. Anacanthorus franciscanus most closely resembles Anacanthorus elegans and A. kruidenieri from the matrinchão, Brycon melanopterus, of the Amazon River Basin. It differs from these species in part by having the bulbous proximal end of the hook shank with two translucent regions. Anacanthorus brevicirrus resembles $A$. franciscanus, A. kruidenieri and A. elegans but is differentiated from these species by its short straight male copulatory organ and by having one translucent region in the bulbous base of the hook shank.
\end{abstract}

Keywords: Monogenoidea, Dactylogyridae, Anacanthorus, Anacanthorus brevicirrus, Anacanthorus franciscanus, Brycon orthotaenia, Rio São Francisco, Brazil

The present study is a continuation of ongoing surveys by personnel of the Universidade Federal Rural do Rio de Janeiro documenting the diversity of parasites infecting the fishes of the Rio São Francisco Basin in Brazil (see Brasil-Sato 2003). In this paper, two new species of Anacanthorus Mizelle et Price, 1965 (Dactylogyridae) are described from the matrinchã, Brycon orthotaenia Günther, a commercially important characiform fish that is currently threatened with extinction in some reaches of the river basin (Lins et al. 1997, Sato 1999). The following species of Monogenoidea have previously been recorded from Brycon spp.: Anacanthorus brevis Mizelle et Kritsky, 1969, Anacanthorus elegans Kritsky, Thatcher et Kayton, 1979, Anacanthorus kruidenieri Kritsky, Thatcher et Kayton, 1979, Anacanthorus spiralocirrus Kritsky, Thatcher et Kayton, 1979, Jainus amazonensis Kritsky, Thatcher et Kayton, 1980 and Tereancistrum kerri Kritsky, Thatcher et Kayton, 1980 (all Dactylogyridae) from matrichão, Brycon melanopterus (Cope) (Mizelle and Kritsky 1969, Kritsky et al. 1979, 1980); Anacanthocotyle sp. (Gyrodactylidae) from Brycon americanus peruanus (host not in FishBase) (Jara 1986); Annulotrematoides bryconi Cuglianna, Cordeiro et Luque, 2003 (Dactylogyridae) from matrinchã, Brycon cephalus (Günther) (Cuglianna et al. 2003); Rhinoxenus anaclaudiae Domingues et Boeger,
2005 (Dactylogyridae) from Brycon sp. (Domingues and Boeger 2005); and Mazocraeoides sp. (Mazocraeidae) from machaca, Brycon quatemalensis Regen (Fucugauchi-Suarez et al. 1988).

\section{MATERIALS AND METHODS}

Specimens of matrinchã were collected from the upper Rio São Francisco near the municipality of Três Marias $\left(18^{\circ} 12^{\prime} 32^{\prime \prime} \mathrm{S}\right.$, $\left.45^{\circ} 15^{\prime} 41^{\prime \prime} \mathrm{W}\right)$, State of Minas Gerais, Brazil, by professional fisherman during July, 2009. Methods of collection and preparation of helminths for study were those of Monteiro et al. (2010). Measurements, all in micrometres $(\mu \mathrm{m})$, are the greatest straight-line distances between extreme points (i.e., distances along curves are not included in the dimension) and are presented as the mean followed by the range and number (n) of specimens measured in parentheses; body length included that of the haptor. Type specimens were deposited in the United States National Parasite Collection, Beltsville, Maryland, USA (USNPC), the Coleção Helmintológica do Instituto Oswaldo Cruz, Rio de Janeiro, Brazil (CHIOC), and the helminth collections of the Instituto Nacional de Pesquisas da Amazônia, Manaus, Amazonas, Brazil (INPA) and of the Institute of Parasitology, Academy of Sciences of the Czech Republic, České Budějovice, Czech Republic (IPCAS) as indicated in the respective descriptions. Voucher specimens of the host were deposited in the Museu de Zoologia, Universidade de São Paulo, São Paulo, Brazil (MZUSP 95166). 


\section{RESULTS}

Anacanthorus franciscanus sp. $\mathrm{n}$.

Figs. 1-4

Description. Body fusiform, 685 (581-828, n=12) long, with narrow cephalic region, broad peduncle, bilobed haptor; greatest body width $95(78-135, \mathrm{n}=12)$ at level of male copulatory organ (MCO). Two terminal, 2 bilateral cephalic lobes well developed; terminal lobes appearing as single lobe when extended. Head organs usually indistinct; cephalic glands not observed. Four eyespots; members of posterior pair slightly farther apart, larger than those of anterior pair; chromatic granules small, subspherical to ovate; few accessory granules scattered in cephalic region. Pharynx subspherical, 34 (29-44, $\mathrm{n}=10$ ) wide; oesophagus elongate. Haptor 66 (51-107, $\mathrm{n}=11)$ long, $80(50-105, \mathrm{n}=12)$ wide; haptoral lobes well developed. Hooks similar in size and shape; each 34 (31-36, $\mathrm{n}=13$ ) long, with proximal bulbous base containing 2 translucent regions, elongate slender shank, reduced thumb, evenly curved shaft and open point; filamentous hook (FH) loop about 1/4 shank length. Single pair of 4As, each $12(10-14, \mathrm{n}=2)$ long, with slight proximal expansion. Gonads tandem or slightly overlapping, intercaecal, lying in posterior half of trunk; testis ovate, 120 (98-152, $\mathrm{n}=6)$ long, $30(20-45, \mathrm{n}=6)$ wide; germarium pyriform, $62(51-78, \mathrm{n}=7)$ long, $32(20-42, \mathrm{n}=6)$ wide. Distal portion of uterus weakly sclerotized; vitellaria comprising 2 bilateral bands of follicles coextensive with oesophagus and intestine; bands confluent at oesophageal level and posterior to gonads; transverse vitelline duct immediately anterior to germarium; vagina absent. MCO $99(93-107, \mathrm{n}=9)$ ) long (from the base to recurve), a long tube lacking developed base, with recurve (reflex) at about $2 / 3$ distance to distal flared tip. Accessory piece $45(40-51, \mathrm{n}=9)$ long, a membranous sheath covering about $1 / 2$ proximal portion of MCO between the base and recurve. Seminal vesicle a simple elongate slight dilation of vas deferens; prostatic reservoir posterior to base of MCO on body midline.

Type host and locality: Matrinchã, Brycon orthotaenia Günther - Rio São Francisco near Três Marias, State of Minas Gerais, Brazil (18 $\left.12^{\prime} 32^{\prime \prime} \mathrm{S}, 45^{\circ} 15^{\prime} 41^{\prime \prime} \mathrm{W}\right)$; 19 July 2009.

Site of infection: Gills.

Specimens studied: Holotype, CHIOC 37330; 21 paratypes, CHIOC 37331a-e, 37332, INPA 524a-f, USNPC 102884, IPCAS M-507.

E ty mology: The specific name refers to the Rio São Francisco from which the helminth was collected.

Remarks. The basic morphology of the MCO and haptoral hooks of $A$. franciscanus closely resembles that of Anacanthorus elegans and Anacanthorus kruidenieri from the matrinchão, Brycon melanopterus, occurring in the Amazon River drainage. Anacanthorus franciscanus is differentiated from the latter two species by the reflex of the MCO occurring at about 2/3 the length from its base (reflex about $1 / 2$ the distance in A. elegans; near the distal tip in $A$. kruidenieri) and by having two translucent regions in the bulbous base of the hook shank (bulbous base small and lacking translucence in A. elegans; base large with one translucent region in A. kruidenieri). Anacanthorus franciscanus differs further from $A$. kruidenieri by having a membranous accessory piece in the copulatory complex (accessory piece rod-shaped in A. kruidenieri) (see Kritsky et al. 1979).

Anacanthorus brevicirrus sp. n.

Figs. 5-8

Description. Body fusiform, $590(476-659, \mathrm{n}=4)$ long, with broad cephalic region, short tapered peduncle, bilobed haptor; greatest body width $79(64-100, \mathrm{n}=4)$ usually posterior to testis. Terminal, 2 bilateral cephalic lobes well developed; terminal lobe may appear double. Three pairs of head organs. Postpharyngeal cephalic glands indistinct, posterolateral to pharynx; prepharyngeal cephalic glands usually visible anterior to eyespots. Four eyespots; members of posterior pair usually slightly farther apart or equidistant, larger than those of anterior pair; chromatic granules small, subspherical to ovate; few accessory granules scattered in cephalic region. Pharynx subspherical, $28(22-32, \mathrm{n}=3)$ wide; oesophagus elongate. Haptor $45(30-58, \mathrm{n}=4)$ long, $64(55-70, \mathrm{n}=4)$ wide; haptoral lobes well developed. Hooks similar in size and shape; each $35(31-37, \mathrm{n}=20)$ long, with small proximal bulbous base containing translucent spot, elongate slender shank, reduced thumb, nearly straight shaft, open point; FH loop about 1/2 shank length. Single pair of 4As, each $10(9-13, n=6)$ long. Gonads tandem or slightly overlapping, intercaecal, lying in posterior half of trunk; testis ovate, $57(47-67, \mathrm{n}=2)$ long, $27(18-36$, $\mathrm{n}=2)$ wide; germarium pyriform, $79(58-118, \mathrm{n}=4)$ long, $32(24-48, \mathrm{n}=4)$ wide. Distal portion of uterus weakly sclerotized (if at all); vitellaria comprising 2 bilateral bands of follicles coextensive with oesophagus and intestine; bands confluent at oesophageal level and posterior to testis; transverse vitelline duct anterior to germarium; vagina absent. MCO $36(30-41, \mathrm{n}=10)$ long, a short broad tube lacking developed base. Accessory piece 16 (11-22, $\mathrm{n}=8$ ) long, a membranous tape-like structure partially encircling distal half of MCO. Seminal vesicle a simple elongate dilation of vas deferens; small prostatic reservoir posterior to base of MCO.

Type host and locality: Matrinchã, Brycon orthotaenia Günther - Rio São Francisco near Três Marias, State of Minas Gerais, Brazil (18 $\left.12^{\prime} 32^{\prime \prime} \mathrm{S}, 45^{\circ} 15^{\prime} 41^{\prime \prime} \mathrm{W}\right) ; 19$ July 2009.

Site of infection: Gills.

Specimens studied: Holotype, CHIOC 37333a; 13 paratypes, CHIOC 37333 b, c, 37334, INPA 523a-c, USNPC 102883, IPCAS M-508. 

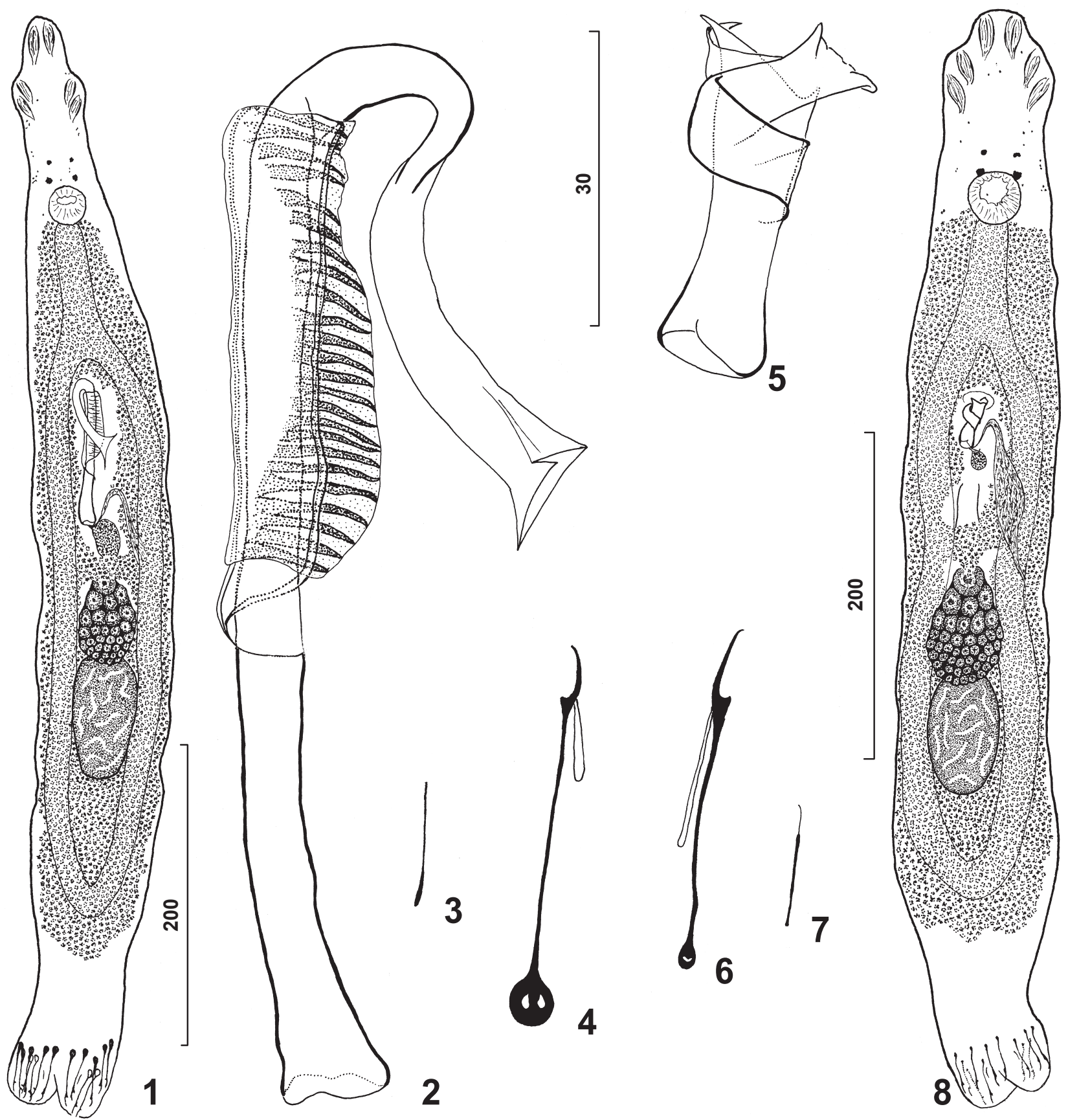

Figs. 1-8. Anacanthorus spp. from the matrinchã, Brycon orthotaenia, from the Rio São Francisco, Brazil. Figs. 1-4. Anacanthorus franciscanus sp. n. Fig. 1. Whole mount (ventral view, composite). Fig. 2. Copulatory complex (ventral view). Fig. 3. 4A. Fig. 4. Hook. Figs. 5-8. Anacanthorus brevicirrus sp. n. Fig. 5. Copulatory complex (ventral view). Fig. 6. Hook. Fig. 7. 4A. Fig. 8. Whole mount (ventral, composite). Figs. 1 and 8 are presented to the respective $200 \mu \mathrm{m}$ scales; Figs. $2-7$ are to the $30 \mu \mathrm{m}$ scale.

E ty m o log y: The specific name is from Latin [brevi $=$ short, cirrus $=\mathrm{a}$ curl (of hair) $]$ and refers to the MCO.

Remarks. Based on the comparative morphology of the hooks, A. brevicirrus apparently shares an evolutionary history with $A$. elegans, $A$. franciscanus and $A$. kruidenieri, all of which are parasites of species of Brycon.
Anacanthorus brevicirrus is easily differentiated from the latter three species by having a short straight MCO (MCO elongate, with recurve in latter three species). Among species of Anacanthorus, only A. euryphallus Kritsky, Boeger et Van Every, 1992 from Triportheus spp. (Characidae) possesses a $\mathrm{MCO}$ comprising a broad short tube 
similar to that of $A$. brevicirrus. However, the accessory piece of A. euryphallus is a branched rod, while that of A. brevicirrus is membranous (see Kritsky et al. 1992).

\section{DISCUSSION}

Anacanthorus currently includes 63 species from the gills of Neotropical characiform fishes (Thatcher 2006) and is primarily characterized by dactylogyrids lacking a vagina and haptoral anchor/bar complexes (Kritsky et al. 1992). The genus was established by Mizelle and Price (1965) for three species from the gills of a red piranha, Serrasalmus nattereri Kner [now Pygocentrus nattereri Kner] (Serrasalmidae), held in the Steinhart Aquarium in San Francisco, California. Of the 42 valid species of Brycon (see Froese and Pauly 2009), only the matrinchão, B. melanopterus from the Amazon Basin, has been previously documented as a host for species of the genus (Mizelle and Kritsky 1969, Kritsky et al. 1979).

All previously described species of Anacanthorus are from fishes of the Amazon River Basin, except Anacanthorus penilabiatus Boeger, Husak et Martins, 1995, which was originally described from Piaractus mesopotamicus (Holmberg) (Serrasalmidae) cultivated in the State of São Paulo, Brazil (Boeger et al. 1995). Anacanthorus penilabiatus has subsequently been reported from P. mesopotamicus, Piaractus brachypomum (Cuvier) and Colossoma macropomum (Cuvier) (all Serrasalmidae), maintained in fish ponds in the Brazilian states of Ceará and São Paulo (Pamplona-Basilio et al. 2001, among others). Cohen and Kohn (2009) also reported A. penilabiatus on P. mesopotamicus from outside the Amazon Basin, but it is unclear from the presentation of the results of their study whether or not the helminth occurred in a natural habitat (Itaipu Hydroelectric Power Station Reservoir on the Paraná River). Finally, Santos (2008) and Albuquerque (2009) recorded unidentified species of Anacanthorus from the gills of Pygocentrus piraya (Cuvier) and Serrasalmus brandtii Lütken (both Serrasalmidae) and Triportheus guentheri (Garman) (Characidae) from the Rio São Francisco drainage, respectively. Thus, A. franciscanus and A. brevicirrus from the Rio São Francisco are the first identified and described members of the genus clearly recorded from a natural habitat outside of the Amazon Basin.

The Rio São Francisco drainage in Brazil shares diverse biological components with those of other river systems in South America (Hubert and Renno 2006). For example, of eight dactylogyrid species occurring on the gills of the catfish, Pimelodus maculatus Lacépède, in the Rio São Francisco Basin, only two, Demidospermus ichthyocercus Monteiro, Kritsky et Brasil-Sato, 2010 and Ameloblastella satoi Monteiro, Kritsky et Brasil-Sato, 2010, are currently restricted to this river system (Monteiro et al. 2010); the remaining six dactylogyrid species on this host also occur in the Platina (Paraná) Drainage of Brazil and Argentina (Kritsky and Gutiérrez 1998, Cohen and Kohn 2008, Santos et al. 2007). The biogeographical explanation for the distributions of these dactylogyrids is in part confounded because of natural and artificial watershed transpositions that have occurred between the Rio São Francisco and the Platina basins (Filho and Buckup 2005) which might have allowed parasite dispersal between the two river systems. Thus, both vicariance and dispersal are likely required to explain extant distributions of these parasites.

The present study suggests that a vicariance/coevolutionary model might be responsible for $A$. franciscanus and A. brevicirrus on B. orthotaenia in the Rio São Francisco. These parasite species are morphologically similar to A. kruidenieri, A. brevis and A. elegans from B. melanopterus from the Amazon River, suggesting that a common ancestor existed for the five dactylogyrid species. Supporting this are the morphological characteristics of the haptoral hooks (straight open point and shaft and presence of translucent regions in the base of the shaft) and copulatory complex (broad tubular MCO and presence of a membranous accessory piece in four of the five species) and the apparent restricted distributions of the respective hosts and their Anacanthorus spp. in the two river systems. In addition, the morphological features of the species of Anacanthorus from Brycon spp. are not shared with any other members of Anacanthorus from unrelated hosts and may represent derived synapomorphic characters that might signal the presence of a monophyletic lineage within the genus (see Kritsky et al. 1992).

Acknowledgements. Dr. Yoshimi Sato, leader of the EPT/ CODEVASF, Três Marias, Minas Gerais, CEMIG-GT/ CODEVASF and UFRRJ/IBAMA, Minas Gerais, is gratefully acknowledged for providing logistical and material support during collections of hosts. CMM was supported by a student fellowship from CAPES (Bex 0750-09-3).

\section{REFERENCES}

Albuquerque M.C. 2009: Taxonomia e aspectos ecológicos da fauna parasitária de Triporteus guentheri (Garson, 1890) e Tetragomopterus chalceus Spix and Agassiz, 1829 do Reservatório de Três Marias, alto do Rio São Francisco, MG, Brasil. Tese do Mestrado, Instituto de Ciências Veterinárias, Universidade Federal Rural do Rio de Janeiro, Seropédica, Rio de Janeiro, Brazil, 126 pp.
Boeger W.A., Husak W.S., Martins M.L. 1995: Neotropical Monogenoidea. 25. Anacanthorus penilabiatus sp. n. (Dactylogyridae, Anacanthorinae) from Piaractus mesopotamicus (Osteichthyes, Serrasalmidae), cultivated in the State of São Paulo, Brazil. Mem. Inst. Oswaldo Cruz 90: 699-701.

Brasil-Sato M.C. 2003: Parasitos de peixes da bacia do São Francisco. In: H.P. Godinho and A.L. Godinho (Eds.), Águas, 
Peixes e Pescadores do São Francisco das Minas Gerais. PUC Minas, Belo Horizonte, Minas Gerais, Brazil, pp. 149-165.

Cohen S.C., Kohn A. 2008: New data on species of Demidospermus (Dactylogyridae: Monogenea) parasitizing fishes from the reservoir of the Itaipu Hydroelectric Power Station, Panana State, Brazil, with new synonymies. Rev. Brasil. Parasitol. Vet. 17: $167-170$.

Cohen S.C., Kohn A. 2009: On Dactylogyridae (Monogenea) of four species of characid fishes from Brazil. Check List 5: $351-356$

Cuglianna A.M., Cordeiro N.S., Luque J.L. 2003: Annulotrematoides bryconi sp. n. (Monogenea: Dactylogyridae) parasitic on Brycon cephalus (Osteichthyes: Characidae) from Brazil. Folia Parasitol. 50: 272-274.

Domingues M., Boeger W. 2005: Phylogeny and coevolution of species of Rhinoxenus (Platyhelminthes, Monogenoidea, Dactylogyridae) and their Characiformes hosts (Teleostei, Ostariophysi) with description of four new species. Zoosystema 27: 441-467.

Filho O.M., Buckup P.A. 2005: A poorly known case of watershed transposition between the São Francisco and upper Paraná river basins. Neotrop. Ichthyol. 3: 449-452.

Froese R., Pauly D. (Eds.) 2009: FishBase. World Wide Web electronic publication. www.fishbase.org, version (06/2009)

Fucugauchi-Suarez M.G.R., García-Magaña L., Brito-ArjoNA B. 1988: Análisis prévio de la parasitofauna de peces de la Laguna Del Rosario, Huimanguillo, Tabasco. Divulgación Cientifica, Diciembre, pp. 319-335.

Hubert N., Renno J.-F. 2006: Historical biogeography of South American freshwater fishes. J. Biogeogr. 33: 1414-1436.

JARA C.A. 1986: Finding of Gyrodactylus sp. and Anacanthocotyle sp. (Monogenea, Gyrodactylidae) in fishes from the Moche River Trujillo, Peru. Hidrobios 10: 8-13.

Kritsky D.C., Boeger W.A., Van Every L.R. 1992: Neotropical Monogenoidea. 17. Anacanthorus Mizelle and Price, 1965 (Dactylogyridae, Anacanthorinae) from characoid fishes of the central Amazon. J. Helminthol. Soc. Wash. 59: 25-51.

Kritsky D.C., Gutiérrez P.A. 1998: Neotropical Monogenoidea. 34. Species of Demidospermus (Dactylogyridae, Ancyrocephalinae) from the gills of pimelodids (Teleostei, Siluriformes) in Argentina. J. Helminthol. Soc. Wash. 65: 147-159.

Kritsky D.C., Thatcher V.E., Kayton R.J. 1979: Neotropical Monogenoidea. 2. The Anacanthorinae Price, 1967, with the proposal of four new species of Anacanthorus Mizelle and Price, 1965, from Amazon fishes. Acta Amazon. 9: 355-361.

Kritsky D.C., Thatcher V.E., Kayton R.J. 1980: Neotropical Monogenoidea. 3. Five new species from South America with the proposal of Tereancistrum gen. n. and Trinibaculum gen. n. (Dactylogyridae: Ancyrocephalinae). Acta Amazon. 10: 411-417.

Lins L.V., Machado A.B.M., Costa C.M.R., Hermann G. 1997: Roteiro metodológico para elaboração de listas de espécies ameaçadas de extinção: contendo a lista oficial de fauna amaeçada de Minas Gerais. Fundação Biodiversitas, Belo Horizonte, Minas Gerais, Brazil, 55 pp.

Mizelle J.D., Kritsky D.C. 1969: Studies on monogenetic trematodes. XL. New species from marine and freshwater fishes. Am. Midl. Nat. 82: 417-428.

Mizelle J.D., Price C.E. 1965: Studies on monogenetic trematodes XXVIII. Gill parasites of the piranha with the proposal of Anacanthorus gen. n. J. Parasitol. 51: 30-36.

Monteiro C.M., Kritsky D.C., Brasil-Sato M.C. 2010: Neotropical Monogenoidea. 55. Dactylogyrids parasitising the pintado-amarelo Pimelodus maculatus Lacépède (Actinopterygii: Pimelodidae) from the Rio São Francisco, Brazil. Syst. Parasitol. 76: 179-190.

Pamplona-Basilio M.C., Kohn A., Feitosa V.A. 2001: New host records and description of the egg of Anacanthorus penilabiatus (Monogenea, Dactylogyridae). Mem. Inst. Oswaldo Cruz 96: 667-668.

Santos M.D. 2008: Comunidades parasitárias de três espécies de peixes carnivoros do Reservatório de Três Marias, alto Rio São Francisco, Minas Gerais. Tese de Doutorado, Instituto de Ciências Veterinárias, Universidade Federal Rural do Rio de Janeiro, Seropédica,, Rio de Janeiro, Brazil, 186 pp.

Santos M.D., Lemos-Pita S.R.L.C., Brasil-Sato M.C. 2007: Metazoan parasite fauna of Pimelodus maculatus La Cépède, 1803 (Siluriformes, Pimelodidae) from the Guandu river, Rio de Janeiro State, Brazil. Acta Scient. Biol. Sci. 29: 101-107.

SAto Y. 1999: Reprodução de peixes da bacia do rio São Francisco: indução e caracterização de padrões. Tese de Doutorado em Ecologia e Recursos Naturais, Centro de Ciências Biológicas e da Saúde, Universidade Federal de São Carlos, São Carlos, Brazil, 179 pp.

Thatcher V.E. 2006: Aquatic Biodiversity in Latin America. Vol. 1. Amazon Fish Parasites. 2nd ed. Pensoft, Sofia-Moscow, 508 pp.

Accepted 8 April 2010 